УДК 94(477)338.43:09

DOI: https://doi.org/10.31652/2411-2143-2020-33-66-73

\author{
Неля Романюк \\ Поліський національний університет \\ доктор історичних наук, професор (Україна) \\ e-mail: kafedra_ppk@ukr.net \\ ORGID: https://orcid.org/0000-0002-2340-4476

\section{Еколого-економічні проблеми використання земельних ресурсів України (1970-1990)}

\begin{abstract}
Анотація. Мета статmі. На основі економічних, сільськогосподарських, історичних досліджень та архівних матеріалів проаналізувати негативні процеси з використання земельних ресурсів у сільському господарстві України в 1970-1990 рр. Методологія дослідження базується на поєднанні загальнонаукових та спеціально-історичних методів з принципами історизму, об'єктивності, системності та міждициплінарності. Наукова новизна. В історичній літературі доповнено характеристику розвитку агропромислового комплексу, зокрема, використання земельних ресурсів України у 1970-1990рр. Проаналізовано еколого-економічну складову. Висновки. У досліджуваний період у сільському господарстві України переважала інтенсивна система землеробства, яка базувалася на отриманні високих врожаїв сільськогосподарських культур за рахунок використання підвищених доз мінеральних добрив, застосування засобів хімічного захисту рослин без урахування екологічних загроз забруднення довкілля. Іенорувалися біологічні, екологічні та економічні закони розвитку галузі. Сільське господарство, з одного боку, потерпало від надмірного, інтенсивного, екологічно необгрунтованого використання земель, а з іншого - теж спричиняло погіршення стану довкілля. Межу екологічної деградації грунту у сільськогосподарському виробництві досягнуто у 1970-і роки, а за 1986-1989 рр. їі перевищено удвічі. Наслідками неправильного застосування хімізації стало забруднення грунтів, сільськогосподарської продукції та довкілля, що було небезпечним для здоров'я людей; зменшення органічних речовин у грунті, погіршення його фізичних властивостей, що знижувало родючість земель. Зростання темпів хімізації землеробства не призвели до бажаного збільшення виробництва
\end{abstract} сільськогосподарської продукції та покращення їі якості.

Ключові слова: земельні ресурси, еколого-економічні проблеми, сільське господарство, забруднення довкілля, Україна.

Постановка проблеми. Головним природним багатством України $є$ земля, являючи собою особливу біологічну, господарсько-економічну та соціальну цінність. Проблеми землекористування $€$ визначальними для розвитку аграрного виробництва, вони $€$ одними 3 найактуальніших в історичному аспекті для сучасності і майбутнього. Якщо виникнення землеробства було першою господарською революцією в цивілізації людства, то введення у практику вирощування рослин обробітку грунту стало першою революцією у землеробстві. Сільське господарство в соціально-економічному житті суспільства функціонує для задоволення найпершої життєвої потреби людей - в продуктах харчування, а також потреб у непродовольчих товарах із сільськогосподарської сировини. Від стану аграрного сектора економіки залежить не тільки рівень життя людей, їх здоров'я, але й соціальне та психічне самопочуття, ставлення до політики, яку проводить держава.

Актуальність статті зумовлена еколого-економічними загрозами у сільському господарстві сучасної України, загостренням проблем раціонального використання і відновлення родючості грунтів. Від того, наскільки економічно ефективно і екологічно безпечно використовується цей засіб виробництва, залежить добробут українського народу.

Аналіз джерел та останніх досліджень. Наявність значної кількості наукових праць 3 розвитку агропромислового комплексу, основних напрямів та наслідків його реформування належить вченим економістам, аграрникам, а в історичних працях ці процеси ще не знайшли достатнього висвітлення. Проблеми використання земельних ресурсів України розглядалися як радянськими дослідниками, так і сучасними науковцями з відповідними відмінностями у підходах та тлумаченні. За останні роки вивченню економічних та екологічних аспектів формування ефективних систем землекористування на загальнодержавному та регіональному рівнях присвячені роботи вчених, зокрема, Д. Добряка [Добряк, Д. С., 2006], М. Богіри [Богіра, М. С., 2008], А. Барвінського [Барвінський, А., 2013], Л. Ковпак [Ковпак, Л. В., 2016]. Однак, зважаючи на продовження практики безсистемного, екологічно необґрунтованого використання земельних ресурсів, незбалансованого розвитку агропромислового сектору, 
потребують подальшого поглибленого дослідження проблеми покращення раціонального використання та охорони земель в історичному аспекті, з урахуванням недоліків минулого.

Мета статті. На основі економічних, сільськогосподарських, історичних досліджень та архівних матеріалів проаналізувати негативні процеси з використання земельних ресурсів у сільському господарстві України в 1970-1990 рр.

Виклад основного матеріалу. У досліджуваний період ігнорувалися національні інтереси українського народу при реалізації напрямів економічного, соціального і культурного потенціалу в рамках колишнього СРСР. Невипадково наприкінці 1980-х - початку 1990-х рр. в Україні проблеми екології постали серед важливих у суспільно-політичному житті. Займаючи близько $2,7 \%$ території колишнього СРСР, на українську республіку припадало майже $25 \%$ усіх промислових забруднень [Передова стаття, $1997: 3]$

Продукція сільського господарства в продовольчому фронді країни в 1989 р. становила $95 \%$, не менше $40 \%$ непродовольчих промислових товарів вироблялося з натуральної сільськогосподарської сировини. Загалом майже 3/4 всього фонду товарів народного вжитку виготовлялося на основі продукції сільського господарства [Медведєв, Лактіонова, 1989 : 4]. Земельний фонд України характеризувався наявністю високого біопродуктивного потенціалу, в структурі якого переважали землі з родючими ґрунтами, на яких розміщувалася основна база землеробства колишнього СРСР. Україна володіла майже 40 \% світової площі найродючіших ґрунтів - чорноземів. При раціональній структурі та організації ефективного, екологічновиваженого землекористування Україна здатна була виробляти продуктів харчування на 140145 млн осіб [Карпов, Сіренький, Данилко, 2001 : 94].

В Україні протягом 1970-1990-х рр. у землекористуванні переважав пріоритет політикоекономічних цінностей над природоохоронними, що зумовило кризу аграрного виробництва. Межу екологічної деградації ґрунту у сільськогосподарському виробництві України на рівні 1520 ГДж/га досягнуто у 1970-ті рр., а за 1986-1989 рр. її перевищено вдвічі [Карпов, Сіренький, Данилко, 2001 : 94]. Стан ґрунтів унаслідок такої інтенсифрікації землеробства істотно змінився, причому характер негативних змін набув широкого розповсюдження. Головною причиною було ігнорування параметрів, а з деяких видів - взагалі відсутність нормативів допустимих меж навантаження на земельні ресурси.

У досліджуваний період концепція інтенсифікації сільського господарства включала три головні напрями: комплексну механізацію, хімізацію та меліорацію. У наукових статтях та книгах із сільського господарства йшлося про механізацію, яка повинна наблизити умови сільськогосподарської праці до індустріальних; хімічні засоби, здатні вирішити проблеми підвищення врожайності; меліорацію, що забезпечить стійкість зовнішніх фракторів виробничого процесу тощо. У сільському господарстві України переважала інтенсивна система землеробства, котра базувалася на одержанні високих урожаїв сільськогосподарських культур за рахунок використання підвищених доз мінеральних добрив, застосування засобів хімічного захисту рослин без врахування екологічних загроз - забруднення довкілля. Ігнорувалися біологічні, екологічні та економічні закони розвитку галузі.

Відсутність наукових концепцій організації сільськогосподарського природокористування призвела до збільшення обсягів ріллі та високої розораності території. Ступінь розораності земель характеризує екологічну нестійкість земельних ресурсів. Найбільш нестійкими в екологічному відношенні $€$ ті райони, в яких розорані землі значно переважають над умовно стабільними, до яких належать сіножаті, пасовища, ліси, чагарники, болота.

Станом на 1987 р. сільськогосподарські угіддя в Україні займали 42,4 млн. га або 70,3% загальної земельної площі, що свідчить про високий рівень залучення земель у господарський обіг. Лише близько 5 млн га (близько 8 \%) перебувало в природному стані. Головними землекористувачами були колгоспи та радгоспи, на долю яких припадало 80,2 \% загальної земельної площі, 98,3 \% сільськогосподарських угідь та 99,3 \% ріллі [Лукинов, Сторожук, Крисальный, 1985 : 159]. В Україні був найвищий рівень розораності угідь порівняно з іншими республіками колишнього СРСР, до того ж сільськогосподарська освоєність земель перевищувала екологічно обґрунтовані норми. В окремих областях України вона досягала 84$86 \%$, а в республіках колишнього СРСР розораність земель дорівнювала 37 \% [Сургай, 1991 : $121]$.

Водночас в Україні щорічно скорочувалася землезабезпеченість. Лише за період 19651985 рр. унаслідок захоплення гігантоманією збудовано сотні промислових підприємств, введено в дію Каховську та Приазовську зрошувальні системи, розпочато будівництво інших великих зрошувальних систем, створено штучні моря на Дніпрі, через що втрачено сотні тисяч гектарів земельних угідь, серед яких безцінні чорноземи, заплавні луки та пасовища. Тільки протягом 1976-1985 рр. щорічні відведення становили близько 10 тис. га, унаслідок чого більш як на 207 тис. га скоротилися площі продуктивних земель [Панченко, 1989 : 13]. Причиною таких невиправданих вилучень із сільськогосподарського обігу найбільш родючих земель було те, що 
безпосередньо земля, як ресурс, з її неповторними властивостями при розрахунках збитків вартості не мала. У зв'язку з цим мало місце намагання знайти для розміщення несільськогосподарських об'єктів такі ділянки землі, щоб сума прямих збитків і розмір компенсаційних виплат були мінімальними, унаслідок чого під відведення потрапляли кращі родючі землі.

Склад сільськогосподарських угідь визначався в основному природними умовами, тому їх структура суттєво відрізнялася природно-кліматичними зонами. Так, для Полісся притаманні лісистість і заболоченість, роздрібненість території, найбільш висока питома вага природних кормових угідь та найменша розораність проти інших зон. У степових та лісостепових районах значно вища сільськогосподарська освоєність території та розораність угідь. Наприклад, в Лісостепу питома вага ріллі становила 85,6 \%, відповідно менше сінокосів та пасовищ.

Загальне уявлення про напрямки використання продуктивних земель дає структура сільськогосподарських угідь, вміщена в табл. 1.

\section{Структура сільськогосподарських угідь України в природно-економічних зонах у 1985 р. (\%).}

Таблиця 1

\begin{tabular}{|c|c|c|c|c|}
\hline Регіон & Орні землі & Багаторічні трави & Сінокоси & Пасовища \\
\hline Україна & 81,6 & 2,5 & 4,9 & 11,0 \\
\hline Полісся & 70,0 & 1,8 & 13,9 & 14,3 \\
\hline Лісостеп & 85,6 & 2,2 & 5,3 & 6,9 \\
\hline Степ & 83,4 & 3,2 & 0,7 & 12,7 \\
\hline
\end{tabular}

Основою сільськогосподарського виробництва $€$ земля. Це визначає роль земельного фонду країни як одного з важливіших видів ресурсів економічного розвитку та найбільш цінної частини національного багатства. В Україні $34,4 \mathrm{Mлн} \mathrm{га} \mathrm{угідь} \mathrm{займали} \mathrm{орні} \mathrm{землі,} 3$ них 32,2 млн га знаходилися в користуванні сільськогосподарських підприємств [Лукінов, Сторожук, Крисальний, $1985: 160]$.

Одним із головних показників для оцінки родючості ґрунту є вміст у ньому комплексу специфічних органічних речовин - гумусу. Від нього залежить не тільки урожайність рослин, але й екологічний стан ґрунтів і ландшафтів, ефективність заходів, спрямованих на підвищення ґрунтової родючості та охорони навколишнього середовища. Гумус - складна багатокомпонентна система - біогенне утворення, джерело живлення як для рослин, так і для мікроорганізмів. Відзначається загально-планетарна роль гумусу як акумулятора енергії на земній поверхні та його санітарно-гігієнічна роль. Узагальнені результати досліджень свідчать про те, що втрати гумусу зумовлені двома головними причинами: ерозією грунтів і переважанням процесів використання гумусу над процесами його відтворення. Станом на 1989 р. досягнутий в Україні рівень внесення органічних та мінеральних добрив компенсував втрати гумусу від ерозії на 60-90 \%, поживних речовин - 40-50 \% [Булыгин, 1989 : 27].

Мінеральні добрива - це концентровані солі елементів мінерального харчування рослин, які змушені споживати все те, чим насичений грунт. За умови недостатку або надлишку одного або декількох елементів харчування, в обміні речовин рослин також виникав дисбаланс, нагромаджувалися залишки небажаних сполучень, внаслідок чого рослини слабо протистояли враженню хворобами та знижували продуктивність. Адаптаційні властивості рослин великі, але й вони не витримували занадто великих навантажень хімізації. Кількість важких металів у фоссфорних добривах, що випускалися у СРСР, у середньому становила (г/т): міді - 127; цинку 164; кадмію - 3,0; свинцю - 34; нікелю - 92; хрому - 121. Істотним недоліком мінеральних добрив та хімічних меліорантів була наявність у них баластних речовин, зокрема й токсичних елементів [Шикула, Гнатенко, Петренко, Капштик, $2001: 123]$.

Наслідками неправильного застосування хімізації стало забруднення сільськогосподарської продукції та довкілля, що було небезпечним для здоров'я людини, зменшення органічних речовин у грунті, погіршення його фізичних властивостей внаслідок ерозії та частих обробок, що знижувало родючість земель. Через недооцінку органічних відходів у сільському господарстві втрачалася велика кількість акумульованої в них енергії та поживних речовин для рослин. Зростання темпів хімізації землеробства не призвели до бажаного збільшення виробництва сільськогосподарської продукції та покращення ії̈ якості.

За півстоліття (1940-1990рр.) виробництво мінеральних добрив у колишньому СРСР, до складу якого входила Україна, збільшилось у 43 рази, пестицидів - у 10, а врожайність зернових збільшилася з 8,6 до 16,2 ц/га, картоплі - з 99 до 113 ц/га. Незважаючи на те, що за період 1970-1990 рр. масштаби використання мінеральних добрив зросли майже в 4 рази, врожайність основних культур практично не змінилась. Так, норми внесення мінеральних добрив під картоплю збільшилися з 142 до 284 кг д.в/га, під цукрові буряки - 230 до 453, льону-довгунця - 
зі 135 до 220 кг д.в/га, а врожайність цих культур не зростала [Милащенко, Захаров, 1991: 3]. Порівнюючи з більшістю країн світу, де у 1970-1990-ті рр. врожайність зростала високими темпами, у колишньому СРСР, зокрема в Україні, досягнуто найменший приріст врожайності в головній галузі - зерновому господарстві (Мынкина, 1995: 48).

У період 1985-1990 рр. в Україні в середньому вносилося 150 кг/га діючої речовини мінеральних та 8,7 т/га органічних добрив. Найбільш високою інтенсивністю використання мінеральних добрив характеризувалася зона Полісся. Тут, у 45 \% адміністративних районів, у цей період щорічно вносили високі та надто високі дози - від 120 до 240 кг/га. За експертними оцінками, для дерново-підзолистих ґрунтів Полісся перевищення середньорічної дози азотних добрив більше 100-120 кг/га діючої речовини негативно впливає на довкілля [Медведєв, Лактіонова, $1989: 84-86]$.

Унаслідок виконання постанови ЦК КПРС і Ради Міністрів від 9 серпня 1979 р. № 765 «Про створення єдиної спеціалізованої агрохімічної служби» в Україні створено республіканське виробничо-наукове об'єднання «Укрсільгоспхімія», обласні та районні виробничі об'єднання «Сільгоспхімія», на які покладалася відповідальність за ефективне, науково обґрунтоване використання в сільському господарстві засобів хімізації, підвищення родючості ґрунтів. До складу Укрсільгоспхімії входило 25 обласних проєктно-розвідувальних станцій хімізації та лабораторій, 84 пункти прогнозу, 293 біолабораторії з виробництва та застосування біологічних засобів захисту рослин [Криштаб, Решитько, 1983 : 15]. Значення хімізації, як найбільш важливого фактора інтенсифікації сільськогосподарського виробництва, підкреслювалося в постанові ЦК КПРС, Ради Міністрів СРСР, прийнятого 12 березня 1981 р. «Про заходи по зміцненню матеріально-технічної служби і підвищенню ефективності хімізації сільського господарства в 1981-1985 рр.»

Проте науково-виробниче об'єднання «Сільгоспхімія», як і інші державні надбудови над сільським господарством, перетворилося в паразитичну монополію, що диктувала колгоспам та радгоспам свої відомчі інтереси. Виробничі фрункції «Сільгоспхімії» за 1980-ті рр. не тільки не розширювалися, але й зводилися до виконання найбільш вигідних робіт. Так, найвигіднішою роботою була доставка та продаж добрив господарствам. Про численні порушення та приписки на підприємствах Житомирської облсільгоспхімії йшлося у доповідній записці начальника відділу сільського господарства обкому партії від 23.04.1984 р. з грифом «Таємно» [ДАЖО. Ф. П-76. Оп. 32. Спр. 133].

Продовжувала мати місце практика неправильного застосування цін, завищення розцінок і тарифрів на хімічну продукцію, виконані роботи та послуги. Так, Бердичівська райсільгоспхімія на Житомирщині лише за 1983 р. обрахувала колгоспи та радгоспи на 5,4 тис. крб. Застосовувалася практика приписок невиконаних робіт, завищення цін на певні види робіт, приховування бюджетних коштів, неправомірної виплати премій та інших порушень фінансової дисципліни [ДАЖО. Ф. П-76. Оп. 32. Спр. 133. Арк. 174]. До того ж із часу виникнення сільгоспхімій колгоспам майже не постачалися автомобілі, гноєрозкидувальні машини, тари для перевезення рідких добрив, машини для внесення туків, внаслідок чого складалося повне непорозуміння з постачанням господарствам мінеральних добрив - нерідко одних - понад норму, інших - 30-40 \% до потреби [ДАЖО. Ф. П-76. Оп. 32. Спр. 133. Арк. 81].

Чимало господарств України не були поінформовані про постачання добрив. Проблема полягала в тому, що мінеральні добрива були фондованим ресурсом, що означало відсутність науково-обґрунтованої системи розподілу фондів мінеральних добрив. Виробництво туків сягало величезних обсягів, але фонди не розподілялися, а ділилися за вольовими та політичними принципами. Тільки у 1985 р. Держагропром СРСР затвердив єдині «Методичні рекомендації по розподілу фондів добрив на 1986-1991 рр.», в яких регламентувалися терміни доведення річних та квартальних фондів зверху донизу.

Щорічне внесення добрив у кількості значно перевищуваних призводило до нагромадження їх у ґрунті. На підставі досліджень доведено, що із загальної кількості азоту мінеральних добрив, який щорічно вносився в ґрунт, 20 \% потрапляло у воду, 24 \% становило газоподібні втрати. Отже, лише 56 \% азоту використовувалося продуктивно. В Україні наприкінці 1989 р. використання мінеральних азотних добрив становило близько 70 кг/га, тоді як у 1960 р. 3,6 кг/га. В окремих регіонах у цей період, коли внесення добрив було максимальним, показник перевищував 70 кг/га [14, с. 148]. Використання мінеральних добрив у підвищених дозах прискорювало процес погіршення гумусу, він швидко втрачав свої агробіологічні властивості, а ґрунт - свою структуру.

Вимоги науково-обґрунтованого, суворо дозованого внесення добрив та пестицидів добре відомі агрономам, проте зазвичай на практиці вони не виконувалися. В архівах станцій хімізації, комітетів народного контролю різних рівнів зберігаються акти перевірок 1980-х рр., в яких наведені численні приклади грубих порушень використання добрив та пестицидів у колгоспах і радгоспах. Гострою була проблема рівномірності розподілу добрив на полі та пестицидів на 
рослину. Технічні засоби, які були в сільському господарстві, не відповідали вимогам, добрива розкидалися роторними машинами, що створювало вогнища залишкового мінерального харчування рослин, знижувало ефективність добрив, якість врожаїв, сприяло збільшенню змивів із поверхні, промиванню вглиб нітратів та інших сполук.

Велика кількість добрив не доходила до полів, вони ставали непридатними для використання внаслідок поганого зберігання. Завдання щодо будівництва сховищ не виконувались щороку. Забезпеченість типовими складами для зберігання пиломістких добрив у середньому в колишньому СРСР, зокрема в Україні, складало всього $20 \%$, а не пиломістких $4 \%$. За офріційними даними, втрати добрив внаслідок незадовільного зберігання складали 1,52 млн т [Милащенко, Захаров, $1991:$ 7]. Проблема економічна (оскільки втрачалися великі кошти) поступово перетворювалася на екологічну, тому що добрива змивалися у водоймища, потрапляли в джерела питної води. Значне накопичення нітратів у ґрунтах та міграція їх у ґрунтові води спостерігали там, де дози мінеральних добрив перевищували можливості засвоєння їх рослинами або строки внесення не співпадали з періодом активного використання рослинами цих добрив.

Використання надмірних доз азотних добрив породжувало й іншу проблему: змінювалася чисельність, видовий та груповий склад мікроорганізмів, розвивалася патогенна мікрофрлора. У зв'язку з цим виникала необхідність у розробці екологічних нормативів на сільськогосподарську діяльність. Так, на початку 1980-х рр. робочою групою з охорони навколишнього середовища в рамках комісії $€ E C$ встановлені максимально допустимі дози внесення азотних добрив для культур за типами ґрунтів. Введені обмеження на щільність поголів'я сільськогосподарських тварин у зонах, що підлягали забрудненню.

Рекомендації з екологічно безпечного використання азотних добрив були розроблені для всіх республік колишнього СРСР та України. У 1988 р. Міністерство охорони здоров'я підвищило рівень максимально допустимих концентрацій (МДК) з нітратів для овочевих культур у 3 рази - 3 80 до 250 міліграм на кілограм ваги овочів. Перегляд норм МДК у сторону підвищення був викликаний введенням безвідомчого контролю за вмістом нітратів. Виявилося, що за дії старих норм близько 90 \% овочевої продукції, яку виробляли колгоспи та радгоспи, не потрапило б до торгівельної мережі. Проте навіть за старими нормами забрудненість багатьох партій овочевої продукції перевищувала МДК у 2-3 і більше разів [Мынкина, $1995: 8$ ].

З 1988 року діяли санітарно-гігієнічні норми «Допустимі рівні вмісту нітратів у продуктах рослинного походження та методи їх визначення», встановлені Міністерством охорони здоров'я СРСР. Систему контролю за якістю продукції здійснювали різні наукові та виробничі підрозділи Міністерства охорони здоров'я, Міністерства сільського господарства, Мінводгоспу України. Особливе місце в цій роботі належало токсикологічним підрозділам, проєктно-пошуковим станціям хімізації сільського господарства та санітарно-епідеміологічним станціям.

Відповідно до рекомендацій, затверджених Держагропромом України, хімічне навантаження на гектар оранки складало (кг/га): на озимині - 189, кукурудзі - 144, зернобобових - 36, картоплі - 127, соняшнику - 47 [Мынкина, 1995 : 8]. Проте наслідки цього хімічного навантаження з накопичення пестицидів у продуктах землеробства та тваринництва залежно від зони і типу ґрунтів не достатньо вивчені, оскільки аналітичних приладів для контролю за вмістом пестицидів у сільськогосподарській продукції та ґрунтах у колишньому СРСР, зокрема й в Україні, не вироблялося. Добрива та інші засоби хімізації повинні були застосовуватися комплексно, у поєднанні з іншими агротехнічними та біологічними прийомами, на основі розвитку фундаментальних, наукових, екологічно збалансованих розробок стосовно використання цих засобів без шкоди для довкілля.

Приблизно 1/10 частину земельних ресурсів України становили меліоровані землі. До 1991 р. вони давали 25 \% вирощеного врожаю. Деякі проєкти меліоративних робіт були ефрективними, зокрема, 400-кілометровий Північно-Кримський канал, Каховська зрошувальна система. Проте не всі розробки були технічно досконалими. Різні оцінки щодо проведених робіт 3 меліорації висловлювали вчені, фрахівці-практики [Мигрин, Коломієць, 2000: 84]. В Україні наприкінці 1980-х - на початку 1990-х рр. були вилучені зі складу меліоративних земель 240 тис. га угідь, які за призначенням не використовувалися, що спричиняло втрату водних джерел, надмірну мінералізацію поливної води, ускладнення рельєфу місцевості тощо. У тих регіонах, де були проведені осушення, відбувалося неконтрольоване зниження потужності органічної маси, а в районах - зрошення, підтоплення і засолення грунтів [Ковпак, 2016 : 142].

Унаслідок руйнівної дії ерозії, посиленої господарської експлуатації, неправильного обробітку, порушення технічних прийомів використання та недбальства землі України щорічно втрачали 20-22 млн т найціннішої речовини - гумусу. Це спричиняло виникнення дефіциту органічних речовин у грунтах. Із грунту забиралося значно більше поживних речовин аніж вносилося [Смолій, 2006 : 578-581]. Українська РСР мала найбільші відсотки еродованих і засолених грунтів. Значна розораність угідь, а також розширення площ під просапні культури 
призвели до посилення ерозійних процесів. Річні втрати грунту становили майже 600 млн т, водночас з 1 га втрачалося 500-700 кг поживних речовин, що у 2-3 рази більше ніж вносилося 3 добривами [Ковпак, $2016: 144]$.

Висновки. У 1970-1990рр. у сільському господарстві України переважала інтенсивна система землеробства, яка базувалася на отриманні високих врожаїв сільськогосподарських культур за рахунок використання підвищених доз мінеральних добрив, застосування засобів хімічного захисту рослин без урахування екологічних загроз - забруднення довкілля. Ігнорувалися біологічні, екологічні та економічні закони розвитку галузі. Сільське господарство, з одного боку, потерпало від надмірного, інтенсивного, екологічно необґрунтованого використання земель, а з іншого боку, теж спричиняло погіршення стану довкілля. Межу екологічної деградації ґрунту у сільськогосподарському виробництві досягнуто у 1970-і роки, а за 19861989 рр. іï̈ перевищено удвічі. Наслідками неправильного застосування хімізації стало забруднення грунтів, сільськогосподарської продукції та довкілля, що було небезпечним для здоров'я людей; зменшення органічних речовин у грунті, погіршення його фрізичних властивостей, що знижувало родючість земель. Зростання темпів хімізації землеробства не призвели до бажаного збільшення виробництва сільськогосподарської продукції та покращення ії якості.

Подяка. Висловлюємо щиру вдячність працівникам архівних установ та бібліотек за сприяння у підготовці статті, а також членам редколегії журналу за консультації, надані під час підготовки статті до друку.

Фінансування. Автор не отримала фрінансової підтримки для дослідження, авторства та / або публікації цієї статті.

Барвінський, А. (2013). Еколого-економічні аспекти формування сталого сільськогосподарського землекористування в ринкових умовах. Землевпорядний вісник, 2, 50 53.

Богіра, М. С. (2008). Землекористування в ринкових умовах: еколого-економічний аспект. Львів: Львівський національний аграрний університет, 225 с.

Булыгин, С. Ю. (1989). Нужна служба охраны почв. Земледелие, 10, 27.

ДАЖО. Державний архів Житомирської області.

Добряк, Д. С. \& Бабміндра, Д. І. (2006). Еколого-економічні засади рефрормування землекористування в ринкових умовах. Київ: Урожай, 333 с.

Карпов, В. І., Данилко, В. К., Климчик, О. М., Колесник, С. І., Рижкова, Л. О., Шатило, В. Й. et al. (2001). Еколого-економічні проблеми довкілля Житомирщини. Житомир: Житомирська облдрукарня, 320 c.

Ковпак, Л. В. (2016). Природоохоронна політика в Україні (1991-2015 роки). Київ: Інститут історії України НАН України, 199 с.

Криштаб, С. Г. \& Решитько, І. Д. (1983). Хімізація - важливий фрактор інтенсифрікації. Київ: Урожай, $56 \mathrm{c}$.

Лукинов, И. И., Сторожук, А. А. \& Крисальный, А. В. (1985). Развитие аграрной экономики Украинской ССР. Киев: Урожай, 414 с.

Мигрин, Г. П. \& Коломієць, С. С. (2000). Екологічна обстановка в сучасній Україні. Екологічні проблеми розбудови громадянського суспільства в сучасній Україні, Київ, 84.

Милащенко, Н. 3. \& Захаров, В. Н. (1991). Производство экологически чистых и биологически полноценных продуктов питання. Химизация сельского хозяйства, 1, 3-12.

Медведев, В. В. \& Лактіонова, Т. М. (1989). Земельні ресурси України. Київ: Аграрна наука, $72 \mathrm{c.}$

Мынкина, Н. Н. (1995). Аграрний сектор экономики СССР: состояние и пути перестройки. Москва: МГУ, 95 с.

Панченко, П. П. (1989). Становище українського села (60-80рр.). Український історичний журнал, 8, 3-14.

Передова стаття (1997). Гарантувати екологічну безпеку планети. Урядовий кур'єр, 26 червня, 3.

Смолій, В. А. (ред.). Історія українського селянства (т. 2). Київ: Наукова думка, 653 с.

Сургай, Г. І. (1991). Сільське господарство Украӥни: уроки минулого і сучасний аграрний курс. Київ: Либідь, 184 с.

Шикула, М. К., Гнатенко, О. Ф., Петренко, Л. Р. \& Капштик, М. В. (2001). Охорона грунтів. Київ: Знання, 400 с. 


\title{
Неля Романюк
}

Полесский государственный университет доктор исторических наук, профессор (Украина)

\section{Эколого-экономические проблемы использования земельных ресурсов Украины (1970-1990)}

\begin{abstract}
Аннотация. Цель статьи. На основе экономических, сельскохозяйственных, исторических исследований и архивных материалов проанализировать негативные процессы по использованию земельных ресурсов в сельском хозяйстве Украины в 19701990 ге. Методология исследования базируется на сочетании общенаучных и специальноисторических методов с принципами историзма, объективности, системности и междисциплинарности. Научная новизна. В исторической литературе дополнена характеристика развития агропромышленного комплекса, в частности, использование земельных ресурсов Украины в 1970-1990 ге. Проанализирована эколого-экономическая составляющая. Выводы. В 1970-1990 г2. в сельском хозяйстве Украины преобладала интенсивная система земледелия, которая базировалась на получении высоких урожаев сельскохозяйственных культур за счет использования повышенных доз минеральных удобрений, применения средств химической защиты растений без учета экологических угроз - загрязнения окружающей среды. Игнорировались биологические, экологические и экономические законы развития отрасли. В исследуемый период сельское хозяйство, с одной стороны, страдало от чрезмерного, интенсивного, экологически необоснованного использования земель, а с другой стороны, тоже вызывало ухудшение состояния окружающей среды. Грань экологической деградации почвы в сельскохозяйственном производстве было достигнуто в 1970-е годы, а за 1986-1989 г2. - превышено вдвое. Последствиями неправильного применения химизации стало загрязнение почвы, сельскохозяйственной продукции и окружающей среды, что было опасным для здоровья людей; уменьшение органических веществ в почве, ухудшение ее физических свойств, что снижало плодородие. Рост темпов химизации земледелия не привел к желаемому увеличению производства сельскохозяйственной продукции и улучшения ее качества.
\end{abstract}

Ключевые слова: земельные ресурсы, эколого-экономические проблемы, сельское хозяйство, загрязнение окружающей среды, Украина.

\author{
Nelia Y. Romaniuk \\ Polissia National University \\ $\operatorname{Dr}$ (History), Professor (Ukraine)
}

\section{Environmental and economic problems of land resources utilization in Ukraine (1970-1990)}

\begin{abstract}
Purpose of the article. The purpose of the article is to analyze negative processes occurring in land resources utilization in agriculture of Ukraine during 1970-1990 based on economic, agricultural historical studies and archive materials. Research methodology is based on the combination of general scientific and special historical methods with the principles of historicism, objectivity, consistency and interdisciplinarity. Scientific vovelty. The historical literature is supplemented with the characteristics of the development of the agro-industrial complex, in particular, the land resources utilization in Ukraine during 1970-1990. The environmental and economic component is analyzed. Conclusions. In 1970-1990, an intensive system of farming dominated in the agriculture of Ukraine. It was based on obtaining high yields of crops through the use of high doses of mineral fertilizers, the application of chemical crop protection products without regard to environmental threats, i.e. environmental pollution. Biological, environmental and economic laws of industry development were ignored. During the period under study, agriculture, on the one hand, suffered from excessive, intensive, environmentally unsound land utilization; on the other hand, also the deterioration of the environment was caused. The limit of environmental soil degradation in agricultural production was reached in the 1970s, and in 1986-1989 it was doubled. Improper application of chemicals has resulted in contamination of soil, agricultural products and the environment, which was hazardous to human health; reduction of organic matter in the soil, deterioration of its physical properties, which reduced soil fertility. The increase in the rate of use of chemicals in agriculture did not lead to the desired increase in agricultural production and improvement of its quality.
\end{abstract}

Key words: land resources, environmental and economic problems, agriculture, environmental pollution, Ukraine. 


\section{References:}

Barvinskyi, A. (2013). Ekoloho-ekonomichni aspekty formuvannia staloho silskohospodarskoho zemlekorystuvannia $v$ rynkovykh umovakh [Ecological and economic aspects of the formation of sustainable agricultural land use in market conditions]. Zemlevporiadnyi visnyk - Land Management Bulletin, 2, 50-53. [in Ukrainian].

Bohira, M. S. (2008). Zemlekorystuvannia v rynkovykh umovakh: ekoloho-ekonomichnyi aspekt [Land use in market conditions: ecological and economic aspect]. Lviv: Lvivskyi natsionalnyi ahrarnyi universytet, 225 p. [in Ukrainian].

Bulygin, S. Yu. (1989). Nuzhna sluzhba okhrany pochv [Need a soil protection service]. Zemledeliye - Agriculture, 10, 27. [in Russian].

DAZhO. Derzhavnyi arkhiv Zhytomyrskoi oblasti [State Archive of Zhytomyr Region] [in Ukrainian].

Dobriak, D. S. \& Babmindra, D. I. (2006). Ekoloho-ekonomichni zasady reformuvannia zemlekorystuvannia $v$ rynkovykh umovakh [Ecological and economic principles of land use reform in market conditions]. Kyiv: Urozhai, 333 p. [in Ukrainian].

Karpov, V. I., Danylko, V. K., Klymchyk, O. M., Kolesnyk, S. I., Ryzhkova, L. O., Shatylo, V. Y. et al. (2001). Ekoloho-ekonomichni problemy dovkillia Zhytomyrshchyny [Ecological and economic problems of the environment of Zhytomyr region]. Zhytomyr: Zhytomyrska obldrukarnia, 320 p. [in Ukrainian].

Kovpak, L. V. (2016). Pryrodookhoronna polityka v Ukraini (1991-2015 roky) [Environmental policy in Ukraine (1991-2015)]. Kyiv: Instytut istorii Ukrainy NAN Ukrainy, 199 p. [in Ukrainian].

Kryshtab, S. H. \& Reshytko, I. D. (1983). Khimizatsiia - vazhlyvyi faktor intensyfikatsii [Chemicalization is an important factor in intensification]. Kyiv: Urozhai, 56 p. [in Ukrainian].

Lukinov, I. I., Storozhuk, A. A. \& Krisalnyy, A. V. (1985). Razvitiye agrarnoy ekonomiki Ukrainskoy SSR [Development of the agrarian economy of the Ukrainian SSR]. Kiyev: Urozhay. 414 p. [in Russian].

Myhryn, H. P. \& Kolomiiets, S. S. (2000). Ekolohichna obstanovka v suchasnii Ukraini [Ecological situation in modern Ukraine]. In Ekolohichni problemy rozbudovy hromadianskoho suspilstva $v$ suchasnii Ukraini (p. 84). Kyiv [in Ukrainian].

Milashchenko, N. Z. \& Zakharov, V. N. (1991). Proizvodstvo ekologicheski chistykh i biologicheski polnotsennykh produktov pitannya [Production of environmentally friendly and biologically complete food products]. Khimizatsiya selskogo khozyaystva - Chemicalization of agriculture, 1, 3-12. [in Russian].

Medvedev, V. V. \& Laktionova, T. M. (1989). Zemelni resursy Ukrainy [Land resources of Ukraine]. Kyiv: Ahrarna nauka, 72 p. [in Ukrainian].

Mynkina, N. N. (1995). Agrarniy sektor ekonomiki SSSR: sostoyaniye i puti perestroyki [Agrarian sector of the USSR economy: state and ways of restructuring]. Moskva: MGU. 95 p. [in Russian].

Panchenko, P. P. (1989). Stanovyshche ukrainskoho sela (60-80 rr.) [The situation of the Ukrainian village (60-80 years).]. Ukrainskyi istorychnyi zhurnal - Ukrainian Historical Journal, 8, 3-14. [in Ukrainian].

Peredova stattia (1997). Harantuvaty ekolohichnu bezpeku planety [Ensure the environmental safety of the planet]. Uriadovyi kurier - Government courier, 26 chervnia, 3. [in Ukrainian].

Smolii, V. A. (Ed.). Istoriia ukrainskoho selianstva [History of the Ukrainian peasantry] (Vol. 2). Kyiv: Naukova dumka, 653 p. [in Ukrainian].

Surhai, H. I. (1991). Silske hospodarstvo Ukrainy: uroky mynuloho i suchasnyi ahrarnyi kurs [Agriculture of Ukraine: lessons of the past and modern agrarian course]. Kyiv: Lybid, 184 p. [in Ukrainian].

Shykula, M. K., Hnatenko, O. F., Petrenko, L. R. \& Kapshtyk, M. V. (2001). Okhorona gruntiv [Soil protection]. Kyiv: Znannia, 400 p. [in Ukrainian]. 